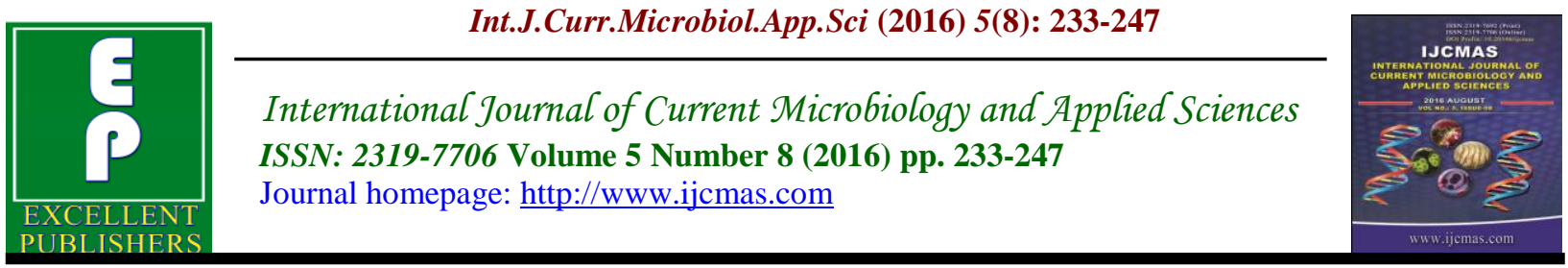

Original Research Article

http://dx.doi.org/10.20546/ijcmas.2016.508.024

\title{
Occurrence of Multi Drug Resistant, ESBL and Carbapenemase Enzymes Producing Gram Negative Urinary Pathogens in Aizawl, Mizoram, India
}

\author{
Karuppasamy Chellapandi*, Lalsanglura Ralte, Manika Basumatari, \\ KSH. Amitra Devi and Rickybirth M. Sangma
}

Department of Medical Laboratory Technology, Regional Institute of Paramedical and Nursing Sciences (RIPANS), Zemabawk, Aizawl, Mizoram, India

*Corresponding author

Keywords

Multi Drug

Resistant,

ESBL,

Carbapenemase

Enzymes.

\section{Article Info}

Accepted:

12 July 2016

Available Online:

10 August 2016

\section{A B S T R A C T}

Urinary Tract Infections (UTI) are one of the commonest bacterial infections; the members of the family Enterobacteriaceae are the most frequent pathogens detected causing UTI. Gram-negative bacteria pose a therapeutic problem not only in the hospital settings, but also in the community as they have acquired resistance to multiple antibiotics. The aim of the study was to assess the prevalence of Gram Negative Bacteria (GNB) causing urinary tract infections and their multiple drug resistance due to ESBL and Carbapenemase production. Bacterial isolates were recovered from the adult patients admitted and attending the Civil Hospital Aizawl, Mizoram for Urinary Tract Infections. Total of $152 \mathrm{GNB}$ isolates were recovered and dominating the entire isolates of UTI pathogens included in this study $(\mathrm{p}<0.05$ (one-tail) and screed for the percentage of Multi Drug Resistance which was also found showing significant increase among the isolates. $(p<0.01)$. There was tendency showing high resistance against cephalosporins, which may be due to the ESBL and carbapenemase enzyme producing capacity by the isolates. The strains belonged to Escherichia coli, Klebsiella spp. were found contributing the higher percentages to the enzymes production. ( $\mathrm{p}<0.001$ ). In summary, the GNB isolates causing UTI recovered from the study region are more notorious and it suggests taking measures to control the further spread of MDR isolates which may be emerging as an important challenge in health care facilities.

\section{Introduction}

Infections with resistant bacterial isolates are emerging as an important challenge in health care facilities. Antimicrobial resistance is associated with adverse outcomes, including increased mortality, hospital stay and costs. In addition, a delay in institution of effective therapy, inferior definitive therapy and greater virulence of some resistant strains are responsible for antimicrobial resistance, (CDC, 2009; CLSI, 2009). Gram-negative bacteria pose a therapeutic problem not only in the hospital settings, but also in the community as they have acquired resistance to multiple antibiotics. The various mechanisms of drug resistance in Gram-negative bacteria include 
extended spectrum beta-lactamases (ESBL) production, AmpC beta-lactamase production, efflux mechanism and porin loss. (Martinez et al., 1999). These enzymes are usually present in integrons on plasmids and pose a serious threat of massive dissemination among the Gram-negative fraternity. (Doumith et al., 2009).

Broad spectrum $\beta$-lactamase producing organisms are a growing worldwide problem (Livermore, 1995). It was first observed in 1983 in isolates of Klebsiella pneumoniae (Knothe et al., 1983). The extended spectrum $\beta$-lactamase (ESBL) producing strains have variable susceptibility rates for fluoroquinolones, aminoglycosides, and fourth-generation cephalosporins (Lautenbach et al., 2001 and Kariuki et al., 2007).

After methicillin resistant staphylococcus aureus (MRSA) and extended spectrum beta lactamases (ESBL), another beta lactamase causing resistance among Gram negative organisms is carbapenemase enzyme. This is an enzyme that hydrolyses a group of antibiotics called carbapenems (Schwaber and Carmeli, 2006; Gary and Margret, 2010). Carbapenems are famously stable to AmpC $\beta$-lactamases and extended-spectrum$\beta$-lactamases (Swenson et al., 2007). This group is considered treatment of choice for infections caused by resistant strains of Gram negative bacteria.

Emergence of carbapenemases in Enterobacteriaceae and non-fermentative bacteria poses a serious therapeutic problem in hospitals because carbapenems are often antibiotics of last resort for the treatment of serious infections caused by multidrugresistant Gram-negative bacteria. Although during the last few years carbapenem resistant Enterobacteriaceae (CRE) has been increasingly reported. Their identification is of primary importance because carbapenemase producers are resistant to almost all $\beta$-lactams and also other class of antibiotics.

Unfortunately, resistance to carbapenems in enterobacteriacae is difficult to detect by routine disc diffusion method used by many microbiology laboratories. Detection of carbapenemases is difficult. It can be detected by phenotypic as well as genotypic methods (Tenover, 2006). Among phenotypic tests, MHT is a relatively easy and simple test to be performed in a laboratory. In January 2009, the CLSI published a recommendation in which carbapenem susceptible Enterobacteriaceae with elevated MICs or reduced disc diffusion inhibition zones should be tested for the production of carbapenemases. For this purpose, the modified Hodge test (MHT) has been widely used as a general phenotypic method for the detection of carbapenemase activity (Bansal et al., 2013), and it is the only recommended method by the CLSI, for carbapenemase detection (CLSI, 2011).

The aim of the present study was to detect the occurrence of $\beta$-lactamase and carbapenemase in clinical isolates of Gram Negative bacilli (GNB) recovered from urine samples of Urinary Tract Infection (UTI) inpatient units and outdoor samples in a tertiary care hospital (Civil Hospital Aizawl) at Aizawl, Mizoram.

\section{Materials and Methods}

\section{Bacterial Isolates}

A total of 156 clinical isolates were included in this study for the screening of their ability to produce Extended Spectrum $\beta$ Lactamases (ESBL) and Carbapenemase. This prospective study was conducted over a 
period of seven months (January to July, 2015) at the Microbiology section, department of Medical Laboratory Technology (MLT), Regional Institute of Paramedical and Nursing Sciences (RIPANS) in Aizawl District, Mizoram, India. The isolates were recovered mainly from the urine samples collected from both diagnosed and suspected to be having Urinary tract infections who are admitted or attending the Major Hospitals in the Aizawl City, Mizoram.

\section{Isolation and Identification of UTI Pathogens}

Pathogens causing UTI were isolated and identified up to their species level by following standard bacteriological methods viz. Lactose and other sugar fermentation, ability to produce Indole, motility of organisms, hemolysis on blood agar, citrate utilization test, Triple Sugar Iron agar (TSI) test etc (Monica Cheesbrough \& Mackie and MacCartney). The organisms were maintained at $4^{\circ} \mathrm{C}$ o agar slants ad at $-20^{\circ} \mathrm{C} \mathrm{I}$ glycerol stocks.

\section{Antimicrobial Susceptibility Testing (AST)}

Briefly, the susceptibility of all the isolates against the antimicrobials was determined by Kirby-Bauer disc diffusion method in Mueller-Hinton agar (Bauer-Kirby, 1966). The inoculum was prepared at a density adjusted to a 0.5 McFarland turbidity standard solution. Commercially available antimicrobial discs (HiMedia Ltd, Mumbai, India) of Ampicillin (A10 $=10 \mu \mathrm{g})$, Ciprofloxacin $\quad(\mathrm{CF} 10=10 \quad \mu \mathrm{g}), \quad \mathrm{Co}-$ trimoxazole $(\mathrm{CO} 25=$ Trimethoprim $2.25 \mu \mathrm{g}$ and Sulphamethoxazole $22.75 \mu \mathrm{g}$ ), Ceftriaxone $(\mathrm{CTR}=10 \quad \mu \mathrm{g})$, Cefixime (CFM5 $=5 \mu \mathrm{g}$ ), Levofloxacin (LE5 $=5 \mu \mathrm{g}$ ), Amoxyclav ( $\mathrm{AC}=10 \mu \mathrm{g}), \quad$ Azithromycin (ATZ 30 $=30 \mu \mathrm{g})$, Norfloxacin $(\mathrm{NX10}=10$ $\mu \mathrm{g}), \quad$ Chloramphenicol $\quad(\mathrm{C}=\quad 10 \quad \mu \mathrm{g})$, Amikacin $(\mathrm{AK} 10 \quad=10 \quad \mu \mathrm{g})$, Penicillin $(\mathrm{P}=30 \mu \mathrm{g})$, Gentamycin $(\mathrm{G} 10=10 \quad \mu \mathrm{g})$, Meropenem $\quad(\mathrm{MRP} 10=10 \quad \mu \mathrm{g})$ and Imepenem (IPM10 $=10 \mu \mathrm{g})$, were placed on the inoculated agar plates and incubated in an upright position overnight at $37^{\circ} \mathrm{C}$. Sensitivity was recorded after $24 \mathrm{hrs}$ of incubation by measuring the zone of inhibition formed around the antimicrobial discs. The results were expressed as Sensitive, Intermediate and Resistant by considering CLSI, 2012 guidelines.

Disc diffusion test was performed using the Kirby-Bauer disc diffusion method to evaluate the sensitivity of test organisms by following the CLSI guidelines ad interpretative criteria. Isolates are subjected to susceptibility to various selective antibiotics (both $\beta$ lactam and non- $\beta$ lactam groups) which includes Ampicillin (), Ciprofloxacin, Levofloxacin, CoTrimaxazole, Ceftriaxone, Cefixime, Amoxyclav, Azithromycin, Norfloxacin, Chloramphenicol, Amikacin, Penicillin, Gentamycin, Imipenem and Meropenem. Any of the isolates that showed reduced susceptibility to any of the $2^{\text {nd }}$ and $3^{\text {rd }}$ generation cephalosporins were subjected to ESBL screening according to the guidelines of the NCCLS (NCCLS, Document. M2. A7. 2000).

\section{ESBL screening test}

All the gram negative isolates were subjected for ESBL production using Double Disc Synergy Test (DDST) methods (NCCLS, 2012). It was carried out using Muller Hinton agar plates that were incubated with standardized medium of the isolates compared to 0.5 McFarland standards to form a lawn cultures. After 15 minutes of pre-incubation, combination discs of Ceftazidime / Ceftazidime clavulanic acid and Cefotaxime/ Cefotaxime 
clavulanic acid were placed $15 \mathrm{~mm}$ apart from each other. Then the plates were incubated at $37^{\circ} \mathrm{C}$ for $18-24$ hours.

Phenotypic detection of carbapenemase production by Modified Hodge test (MHT)

All the gram negative isolates were subjected to Modified Hodge test as per CLSI guidelines. All the isolates showed reduced susceptibility to Meropenem (diameter zone of inhibition $\leq 21 \mathrm{~mm}$ ) were considered as screening positive for the Carbapenemase production and further confirmed by phenotypic confirmatory method - Modified Hodge Test.(CLSI, 2011).

A lawn culture of the 1:10 dilution of Escherichia coli ATCC 25922 as recommended by CLSI was done on Mueller Hinton agar plate and a 10- g meropenem susceptibility disk was placed in the centre of the test area.

The test organism was then streaked in a straight line from the edge of the disk to the edge of the plate. Four strains were tested on the same plate with one disk and were incubated overnight at $35^{\circ} \mathrm{C} \pm 2^{\circ} \mathrm{C}$ for 18 24 hours.

Interpretation was done after 18 - 24 hours of incubation. Positive Modified Hodge test showed a clover leaf-like indentation of the Escherichia coli 25922 strain growing along the test organism growth streak within the disk diffusion zone indicating production of carbapenemase and a negative test showed no growth of the Escherichia coli ATCC 25922 along the test organism growth streak within the disk diffusion (CLSI, 2011).

\section{Results and Discussion}

Identification and confirmation of isolates were done on the basis of morphological, biochemical and phenotypic characteristics. Bacterial isolates were isolated and identified upto the Genus level by sub culturing to MacConkey agar, Cystein Lactose Electrolyte Deficient (CLED) agar and Mannitol Salt Agar (MSA) and incubated at $37{ }^{\circ} \mathrm{C}$ for $24 \mathrm{~h}$. By standard bacteriological tests viz. Gram staining, catalase test, coagulase test, IMViC, Triple Sugar Iron Agar (TSI) tests, Motility test and Eosin Methylene Blue (EMB) agar were used to identify to the genus level.

\section{Percentage of isolates occurrence}

Among the 156 isolates recovered from urine specimens, $121(77.57 \%)$ are Gram negative bacilli, 31 (19.87\%) are Gram positive cocci and $04(02.56 \%)$ of the isolates were belonged to Candida species (Table.1). It is clear that E.coli was the predominant uropathogens $(31.41 \%)$ causing UTI, followed by Staphylococcus aureus (15.38\%), Klebsiella species (13.46\%), Proteus species (10.26\%) and Pseudomonas aeruginosa (06.41\%). However, Enterococcus faecalis (01.92\%), Staphylococcus saprophyticus (02.56\%), Acinetobacter baumanni (3.21\%) and Salmonella species $(03.21 \%)$ were found to be the least dominant uropathogens causing UTI strains (Table.1)

\section{Antimicrobial resistance}

Antibiotic resistance is a worldwide problem in the medical society that continues to grow. Almost all the isolates were found to be multidrug resistant i.e. the isolates shown resistance to at least five antimicrobial agents out of 15 selected antimicrobial agents in this study. An antibiogram study of 152 bacteria1 isolates showed that the percentage of resistance was very high. Among the 152 bacterial isolates tested for drug resistance the higher percentage of 
resistance was found against Ampicillin (82.24\%), followed by $65.13 \%$ resistance to Co-Timoxazole, $64.47 \%$ to Amoxycillin, $59.87 \%$ to Penicillin and $57.24 \%$ to Norfloxacin at high level of percentage (Table 3). The antibiotics to which maximum isolates found sensitive were against Imepenem, Meropenem, Chloramphenicol, Amikacin and gentamicin where only $9.21 \%, 12.5 \%, 18.42 \%, 19.74 \%$ and $20.39 \%$ of isolates were found resistant to these antibiotics respectively. These experimental results also suggested that multi drug resistance of UTI causing bacterial pathogens is increasing and almost all the isolates were resistant to more than five antibiotics. In this antibiogram study 15 antibiotics were used and any bacteria shows resistance to more than 5 antibiotics was considered to be Multi Drug Resistant (MDR) isolates. Almost all the isolated genus was showing resistance to all the antibiotics used. E. coli, Klebsiella spp., S. aureus and Proteus spp. are the genera found contributed high percentage to MDR than the other genera recovered. The MDR analysis has shown that $63.82 \%$ of the isolates are MDR and only $36.18 \%$ are NonMDR isolates.

\section{Extended spectrum of $\beta$-lactamases}

All the Gram negative isolates have been tested for the Extended spectrum $\beta$ lactamase enzymes (ESBL) by standard bacteriological double diffusion synergy test (DDST) methods (CLSI, 2012). Of all the members of Enterobacteriaceae Gram Negative Bacilli (GNB) isolates E.coli, Klebsiella spp. Proteus spp. and Pseudomonas spp. were found to be the highest ESBL producers that $11.57 \%$, $12.40 \%, 4.96 \%$ and $02.48 \%$ respectively. Followed by E.coli, Klebsiella, Proteus and Pseudomonas spp., Enterobacter spp. (02.48\%), Citrobacter spp. (02.48\%) and
Acinetobacter spp. (00.83\%) contributes very less percentage of ESBL productions, but $0 \%$ of isolates found positive for ESBL from the genus Salmonella spp. (Table 4).

\section{Distribution of Carbapenemase producers}

Out of the total $19.83 \%$ (Meropenem screen positive) clinical isolates, E.coli and Klebsiella spp. showed $03.31 \%$ and $06.61 \%$ carbapenemase production respectively. Among 6 isolates of E.coli and 2 isolates of Klebsiella spp. has shown resistant to Meropenem were all found to be positive for carbapenemase production by Modified Hodge Test (MHT). Citrobacter spp. (3.31\%), Pseudomonas spp. (3.31\%), Proteus spp. (2.48\%) and Enterobacter spp. $(1.65 \%)$ contributed very less percentages to the carbapenemase production test. None of the isolates from the Genus Salmonella and Acinetobacter spp. were found positive.

Urinary Tract Infections (UTI) are one of the commonest bacterial infections. The members of the family Enterobacteriaceae are the most frequent pathogens detected causes UTI (Wada et al., 2009 and Gale et al., 1998). The present study is conducted to achieve the resistance profile of clinical isolates from the study area against commonly prescribed antibiotics. The results of our current findings show higher degree of resistance to almost all antibiotics as compared to previously reported studies from the study region.

A total of 156 clinical isolates were recovered from the urine samples collected form both diagnosed and suspected to have UTI cases who are admitted or attending the Civil Hospital Aizawl (CHA). Each sample was inoculated on both blood agar (with 5\% Sheep blood) and MacConkey agar plates and incubated at $37 \mathrm{oC}$ for 24- 48 hours. 
Significant growths of isolates were further subjected to standard bacteriological and biochemical methods to identify the isolates to their genus and species (CLSI, 2011).

\section{Percentage distribution of isolates}

A summary of the different microorganisms isolated in this preset study is show in Table.1. It is clear that Escherichia coli (31.4\%) were the predominant uropathogens causing UTI followed by Staphylococcus aureus (15.4\%), Klebsiella spp. (13.5\%), Proteus spp. (10.3\%) and Pseudomonas aeruginosa (6.4\%). However, Enterococcus faecalis (1.9\%), Staphylococcus saprophyticus (2.6\%), Acinetobacter baumanni (3.2\%), Salmonella spp. (3.2\%), Citrobacter spp. (3.9\%) and Enterobacter spp. (5.8\%) were the least dominant uropathogens causing UTI. (Karuppasamy and Lalsaglura, 2012; Manikandan and Amsath, 2014).

\section{Antimicrobial resistance}

An antibiogram study of 152 bacteria1 isolates showed that the percentage of resistance was very high. Among the 152 bacterial isolates tested for drug resistance the higher percentage of resistance was found against Ampicillin (82.24\%), followed by $65.13 \%$ resistance to CoTimoxazole, $64.47 \%$ to Amoxycillin, 59.87 $\%$ to Penicillin and $57.24 \%$ to Ceftriaxone at high level of percentage. (Table 3). The ampicillin resistance among the isolates is probably due to continuous use of it for many years. Earlier it has been reported tat the ampicillin has no more effect on urinary tract pathogens in United States of America. (Sahm et al., 2000). Co-Trimaxazole and Amoxycillin resistance is also a emerging at high degree in our region, similar reports are also found from other regions of the country (Maikandan et al., 2011).
Among cephalosporins, high degree of resistance were found against Ceftriaxone (46.7\%), and Cefixime (46\%), similar results were reported form other countries. (Ko et al., 2008) reported $100 \%$ and $38 \%$ resistance against cefotaxime and ceftazidime among ESBL producing isolates of E.coli and $73 \%$ resistance of ceftriaxone from Iran by Mehrgan and Ranbar, 2008. Although the higher degrees of resistance shown by UTI pathogens against wide range of antibiotics, they showed a least resistance against old drugs like Gentamicin, may be due to its multiple mechanisms of action have enabled it to retain potent activity against the pathogens.

Although resistance rate to Amikacin (19.7\%), Meropenem (12.5\%) and Imipenem (9.2\%) are less, it's quite increased now than the previous report by the author form this study area. Report by the author from this study area in the year 2012 UTI pathogens showed the least resistance against Amikacin (7.4\%), Meropenem (0\%) and Imipenem (0\%). (Karuppasamy and Lalsanglura, 2012). Increasing resistance to these antibiotics indicates that these antibiotics are often used in treatment in present days; more use of these antibiotics also indicates that there is a escalation of high rate of resistance against all the commonly prescribed therapeutic drugs in the past.

The over all resistance rate against the Amino glycosides (Amikacin and Gentamicin), Chloramphenicol and Carbapenem (Meropenem and Imipenem) were found to be the least contributions by UTI pathogens. (Manikandan and Amsath, 2014; Karuppasamy et al., 2015). In this study the Multi Drug Resistance (MDR) rates were also been found in significant level among the UTI pathogens. Isolates of each genus group have shown wide range of 
MDR patterns resisting from 2 to 12 drugs among the 15 antibiotics selected for the current study (Data not shown).

The MDR pattern was very complex in the genus of E.coli and Klebsiella spp. but in S. aureus though the percentage of MDR is high, MDR pattern was not as complex as E.coli and Klebsiella spp.; S. aureus mostly showed MDR to Penicillin group antibiotics and least Cephalosporins and Carbapenems. (Manikandan et al., 2011).

\section{ESBL}

Extended Spectrum $\beta$ Lactamases (ESBLs) are a group of enzymes that have the common property of providing resistance to extended-spectrum $\beta$ lactam antibiotics such as Oxyimino cephalosporins (e.g. cefotaxime, ceftazidime, ceftriaxone, cefepime and cefpirome), as well to aztreonam an oxyimino monobactam, Cephamycins (Cefoxitin and cefotetan) and Carbapenems (Imepenem and Meropenem) (Oreste, 2003). All the gram negative isolates have been tested for the extended spectrum $\beta$ - lactamase enzymes (ESBL) by standard bacteriological double diffusion synergy test (DDST) methods (CLSI, 2012).

Of all the members of Enterobacteriaceae Gram Negative Bacilli (GNB) isolates of $E$. coli and Klebsiella spp. were found to be the highest ESBL producers that $11.6 \%$ and $12.4 \%$ of isolates were positive for ESBL's. Proteus spp. (4.9\%), Pseudomonas spp. (2.5\%), Enterobacter spp. (2.5\%), Citrobacter spp. (2.5\%). and Acinetobacter $(0.8 \%)$. contributes very less percentage of ESBL productions (Table.4). In this study $45(37.19 \%)$ strains out of $121 \mathrm{GNB}$ found to be positive for the ESBLs double disk synergy test.
In the present study, it was observed that ESBL producing strains exhibited high levels of multi drug resistance and the prevalence of ESBL producing Klebsiella spp. and E.coli were found to be contributed high percentage that $12.4 \%$ and $11.6 \%$ respectively. From India high prevalence of ESBL producing Klebsiella strains has been reported by various groups. (Rastogi et al., 2010). Prevalence of ESBL producing Klebsiella strains around the world varies between $3 \%$ - $8 \%$ to $100 \%$ (Ferreira et al., 2011).

Amongst GNBs, commonest organism have shown positive for the ESBL Synergy test are Klebsiella spp and E. coli. In the last decade ESBL have gone from being interesting scientific observation to a reality of great medical importance. Initially restricted to the hospital acquired infections, now they have also been reported form out patients and even from food sources. (Prakash et al., 2012; Karuppasamy et al., 2015; Shahid et al., 2009).

In many recent studies in India and abroad showed the similar findings of our current study. (Babypadmini et al., 2004; Daoud et al., 2006; Mustafa et al., 2009; Faith et al., 2003)

The ESBL producing bacteria have significant impact on antimicrobial therapy and infection control. These bacteria are multiply resistant to the different classes of antibiotics and are more frequently seen in patients admitted to the intensive care units where morbidity and mortality rates are higher, directly or indirectly due to ESBLproducing bacteria. 
Table.1 Percentage of isolation frequency of UTI causing pathogens

\begin{tabular}{|l|l|l|l|}
\hline S.No & Organisms & No. of isolates & \% of isolation \\
\hline $\mathbf{1 .}$ & Escherichia coli & 49 & 31.41 \\
\hline $\mathbf{2 .}$ & Klebsiella species. & 21 & 13.46 \\
\hline $\mathbf{3 .}$ & Proteus species. & 16 & 10.26 \\
\hline $\mathbf{4 .}$ & Pseudomonas species. & 10 & 06.41 \\
\hline $\mathbf{5 .}$ & Enterobacter species. & 09 & 05.77 \\
\hline $\mathbf{6 .}$ & Citrobacter species. & 06 & 03.85 \\
\hline $\mathbf{7 .}$ & Salmonella species. & 05 & 03.21 \\
\hline $\mathbf{8 .}$ & Acinetobacter baumanni. & 05 & 03.21 \\
\hline $\mathbf{9 .}$ & Enterococcus faecalis. & 03 & 01.92 \\
\hline $\mathbf{1 0 .}$ & Staphylococcus aureus. & 24 & 15.38 \\
\hline $\mathbf{1 1 .}$ & Staphylococcus saprophyticus. & 04 & 02.56 \\
\hline $\mathbf{1 2 .}$ & Candida species. & 04 & 02.56 \\
\hline TOTAL & $\mathbf{1 5 6}$ & $\mathbf{1 0 0 . 0 0}$ \\
\hline
\end{tabular}

Table.2 Percentage of Multi Drug Resistance of bacterial isolates recovered.

\begin{tabular}{|l|l|l|l|}
\hline S.No & Organisms & $\begin{array}{l}\text { \% of isolation } \\
(\# \mathbf{1 5 6})\end{array}$ & $\begin{array}{l}\text { \% of MDR of } \\
\text { bacterial isolates (\#152) }\end{array}$ \\
\hline 1. & E.coli $(49)$ & 31.41 & $31(20.39)$ \\
\hline 2. & Klebsiella sp. $(21)$ & 13.46 & $17(11.18)$ \\
\hline 3. & Proteus sp. $(16)$ & 10.26 & $12(07.89)$ \\
\hline 4. & Pseudomonas aeruginosa $(10)$ & 06.41 & $08(05.26)$ \\
\hline 5. & Enterobacter sp. $(09)$ & 05.77 & $05(03.29)$ \\
\hline 6. & Citrobacter sp. $(06)$ & 03.85 & $04(02.63)$ \\
\hline 7. & Salmonella sp. $(05)$ & 03.21 & $02(01.32)$ \\
\hline 8. & Acinetobacter baumanni. $(05)$ & 03.21 & $02(01.32)$ \\
\hline 9. & Enterococcus faecalis. $(03)$ & 01.92 & $02(01.32)$ \\
\hline 10. & S. aureus. (24) & 15.38 & $17(11.18)$ \\
\hline 11. & S. saprophyticus. $(04)$ & 02.56 & $02(01.32)$ \\
\hline TOTAL & Total isolates $=\mathbf{1 5 2}$ & $\mathbf{1 0 2}(\mathbf{6 7 . 1 1})$ \\
\hline
\end{tabular}


Table.3 Percentage of Drug Resistance of 152 bacterial pathogens against antimicrobial agents.

\begin{tabular}{|c|c|c|c|c|}
\hline \multirow[t]{2}{*}{ S.No } & \multirow[t]{2}{*}{ Antimicrobials } & \multicolumn{3}{|c|}{$\%$ of DRP $(n=152)$} \\
\hline & & Susceptible (\%) & $\begin{array}{l}\text { Intermediate } \\
(\%)\end{array}$ & $\begin{array}{l}\text { Resistant } \\
(\%)\end{array}$ \\
\hline 1. & Ampicillin & $\begin{array}{l}\mathbf{1 8} \\
(11.84)\end{array}$ & $\begin{array}{l}\mathbf{0 9} \\
(05.92)\end{array}$ & $\begin{array}{l}125 \\
(82.24)\end{array}$ \\
\hline 2. & Co-Trimaxazole & $\begin{array}{l}39 \\
(25.66)\end{array}$ & $\begin{array}{l}\mathbf{1 4} \\
(09.21)\end{array}$ & $\begin{array}{l}\mathbf{9 9} \\
(65.13)\end{array}$ \\
\hline 3. & Amoxycillin & $\begin{array}{l}\mathbf{3 1} \\
(20.39)\end{array}$ & $\begin{array}{l}\mathbf{2 3} \\
(15.13)\end{array}$ & $\begin{array}{l}\mathbf{9 8} \\
(64.47)\end{array}$ \\
\hline 4. & Penicillin & $\begin{array}{l}36 \\
(23.68)\end{array}$ & $\begin{array}{l}\mathbf{2 5} \\
(16.45)\end{array}$ & $\begin{array}{l}91 \\
(59.87)\end{array}$ \\
\hline 5. & Norfloxacin & $\begin{array}{l}\mathbf{4 3} \\
(28.29)\end{array}$ & $\begin{array}{l}22 \\
(14.47)\end{array}$ & $\begin{array}{l}\mathbf{8 7} \\
(57.24)\end{array}$ \\
\hline 6. & Ceftriaxone & $\begin{array}{l}64 \\
(42.11) \\
\end{array}$ & $\begin{array}{l}\mathbf{1 7} \\
(11.18)\end{array}$ & $\begin{array}{l}\mathbf{7 1} \\
(46.71)\end{array}$ \\
\hline 7. & Cefixime & $\begin{array}{l}\mathbf{5 5} \\
(36.18)\end{array}$ & $\begin{array}{l}27 \\
(17.76)\end{array}$ & $\begin{array}{l}\mathbf{7 0} \\
(46.05)\end{array}$ \\
\hline 8. & Levofloxacin & $\begin{array}{l}69 \\
(45.39)\end{array}$ & $\begin{array}{l}\mathbf{2 8} \\
(18.42)\end{array}$ & $\begin{array}{l}\mathbf{5 5} \\
(36.18)\end{array}$ \\
\hline 9. & Ciprofloxacin & $\begin{array}{l}\mathbf{6 6} \\
(43.42)\end{array}$ & $\begin{array}{l}\mathbf{3 2} \\
(21.05)\end{array}$ & $\begin{array}{l}\mathbf{5 4} \\
(35.53)\end{array}$ \\
\hline 10. & Azithromycin & $\begin{array}{l}\mathbf{7 2} \\
(47.37)\end{array}$ & $\begin{array}{l}\mathbf{3 3} \\
(21.71)\end{array}$ & $\begin{array}{l}\mathbf{4 7} \\
(30.92)\end{array}$ \\
\hline 11. & Gentamicin & $\begin{array}{l}97 \\
(63.82)\end{array}$ & $\begin{array}{l}\mathbf{2 4} \\
(15.79)\end{array}$ & $\begin{array}{l}\mathbf{3 1} \\
(20.39)\end{array}$ \\
\hline 12. & Amikacin & $\begin{array}{l}\mathbf{1 0 4} \\
(68.42)\end{array}$ & $\begin{array}{l}\mathbf{1 8} \\
(11.84)\end{array}$ & $\begin{array}{l}\mathbf{3 0} \\
(19.74)\end{array}$ \\
\hline 13. & Chloramphenicol & $\begin{array}{l}\mathbf{1 0 8} \\
(71.05)\end{array}$ & $\begin{array}{l}\mathbf{1 9} \\
(12.5)\end{array}$ & $\begin{array}{l}\mathbf{2 8} \\
(18.42)\end{array}$ \\
\hline 14. & Meropenem & $\begin{array}{l}\mathbf{1 0 8} \\
(71.05)\end{array}$ & $\begin{array}{l}\mathbf{2 5} \\
(16.45)\end{array}$ & $\begin{array}{l}\mathbf{1 9} \\
(12.5)\end{array}$ \\
\hline 15. & Imepenem & $\begin{array}{l}\mathbf{1 1 7} \\
(76.97)\end{array}$ & $\begin{array}{l}\mathbf{2 1} \\
(13.82)\end{array}$ & $\begin{array}{l}\mathbf{1 4} \\
(09.21)\end{array}$ \\
\hline \multicolumn{2}{|c|}{ TOTAL (\% of resistance) } & 45.0 & 14.7 & 40.3 \\
\hline
\end{tabular}


Table.4 Percentage of Drug Resistance Patterns (DRP) of 152 bacterial pathogens against antimicrobial agents

\begin{tabular}{|c|c|c|c|c|c|c|c|c|c|c|c|c|c|c|c|c|c|}
\hline $\begin{array}{l}\text { Sl. } \\
\text { no. }\end{array}$ & $\begin{array}{c}\text { Organism } \\
\text { (No. of isolates) }\end{array}$ & $\sum_{i}$ & $U_{<}$ & Ne & $\frac{1}{4}$ & Z到的 & $\hat{z}_{i}$ & $\sum_{\Theta}$ & $\stackrel{\theta}{a}$ & e & 芠 & $\sum_{\substack{x \\
ن}}$ & 彭 & อิ & 贫气 & $\overline{\mathrm{z}} 0$ & $\sum \simeq \sqrt[\theta]{\theta}$ \\
\hline 1. & $\begin{array}{c}\text { E.coli } \\
(49)\end{array}$ & \begin{tabular}{|c|}
40 \\
$(81.63)$ \\
\end{tabular} & $\begin{array}{c}31 \\
(63.27) \\
\end{array}$ & $\begin{array}{c}10 \\
(20.41) \\
\end{array}$ & $\begin{array}{c}04 \\
(08.16) \\
\end{array}$ & $\begin{array}{c}02 \\
(04.08) \\
\end{array}$ & $\begin{array}{c}06 \\
(12.24) \\
\end{array}$ & $\begin{array}{c}02 \\
(04.08) \\
\end{array}$ & $\begin{array}{c}32 \\
(65.31) \\
\end{array}$ & $\begin{array}{c}12 \\
(24.48) \\
\end{array}$ & $\begin{array}{c}31 \\
(63.27) \\
\end{array}$ & $\begin{array}{c}31 \\
(63.27) \\
\end{array}$ & $\begin{array}{c}18 \\
(36.73) \\
\end{array}$ & $\begin{array}{c}32 \\
(65.31) \\
\end{array}$ & $\begin{array}{c}17 \\
(34.69) \\
\end{array}$ & $\begin{array}{c}11 \\
(22.45) \\
\end{array}$ & $\begin{array}{c}31 \\
(63.27) \\
\end{array}$ \\
\hline 2. & Klebsiella sp. (21) & $\begin{array}{c}17 \\
(80.95)\end{array}$ & $\begin{array}{c}12 \\
(57.14)\end{array}$ & $\begin{array}{c}04 \\
(19.05)\end{array}$ & $\begin{array}{c}02 \\
(09.52)\end{array}$ & $\begin{array}{c}04 \\
(19.05)\end{array}$ & $\begin{array}{c}02 \\
(09.52)\end{array}$ & $\begin{array}{c}01 \\
(04.76)\end{array}$ & $\begin{array}{c}08 \\
(38.10)\end{array}$ & $\begin{array}{c}03 \\
(14.29)\end{array}$ & $\begin{array}{c}10 \\
(47.62)\end{array}$ & $\begin{array}{c}08 \\
(38.10)\end{array}$ & $\begin{array}{c}09 \\
(42.86)\end{array}$ & $\begin{array}{c}11 \\
(52.38)\end{array}$ & $\begin{array}{c}13 \\
(61.90)\end{array}$ & $\begin{array}{c}10 \\
(47.62)\end{array}$ & $\begin{array}{c}17 \\
(80.95) \\
\end{array}$ \\
\hline 3. & Proteus sp. (16) & \begin{tabular}{|c|}
09 \\
$(56.25)$ \\
\end{tabular} & $\begin{array}{c}08 \\
(50)\end{array}$ & $\begin{array}{c}06 \\
(37.50) \\
\end{array}$ & $\begin{array}{c}03 \\
(18.75) \\
\end{array}$ & $\begin{array}{c}08 \\
(05.26) \\
\end{array}$ & $\begin{array}{c}07 \\
(50)\end{array}$ & $\begin{array}{c}02 \\
(12.50) \\
\end{array}$ & $\begin{array}{c}07 \\
(43.75) \\
\end{array}$ & $\begin{array}{c}06 \\
(37.50) \\
\end{array}$ & $\begin{array}{c}08 \\
(50) \\
\end{array}$ & $\begin{array}{c}09 \\
(56.25) \\
\end{array}$ & $\begin{array}{c}08 \\
(50) \\
\end{array}$ & $\begin{array}{c}11 \\
(68.75) \\
\end{array}$ & \begin{tabular}{|c|}
06 \\
$(37.50)$ \\
\end{tabular} & $\begin{array}{c}07 \\
(43.75) \\
\end{array}$ & $\begin{array}{c}12 \\
(75)\end{array}$ \\
\hline 4. & P. aeru & $\begin{array}{c}10 \\
(100)\end{array}$ & $\begin{array}{c}08 \\
(80)\end{array}$ & $\begin{array}{c}04 \\
(40)\end{array}$ & $\begin{array}{c}03 \\
(30)\end{array}$ & $\begin{array}{c}04 \\
(40)\end{array}$ & $\begin{array}{c}02 \\
(20)\end{array}$ & $\begin{array}{c}01 \\
(10)\end{array}$ & $\begin{array}{c}08 \\
(80)\end{array}$ & $\begin{array}{c}04 \\
(40)\end{array}$ & $\begin{array}{c}08 \\
(80)\end{array}$ & $\begin{array}{c}07 \\
(70)\end{array}$ & $\begin{array}{c}09 \\
(90)\end{array}$ & $\begin{array}{c}08 \\
(80)\end{array}$ & $\begin{array}{c}03 \\
(30)\end{array}$ & $\begin{array}{c}04 \\
(40)\end{array}$ & $\begin{array}{c}08 \\
(80)\end{array}$ \\
\hline 5. & Enterobacte & \begin{tabular}{|c|}
08 \\
$(88.89)$ \\
\end{tabular} & $\begin{array}{c}05 \\
(55.56) \\
\end{array}$ & $\begin{array}{c}04 \\
(44.44) \\
\end{array}$ & $\begin{array}{c}02 \\
(22.22) \\
\end{array}$ & $\begin{array}{c}03 \\
(33.33) \\
\end{array}$ & $\begin{array}{c}02 \\
(22.22) \\
\end{array}$ & $\begin{array}{c}01 \\
(11.11) \\
\end{array}$ & $\begin{array}{c}04 \\
(44.44) \\
\end{array}$ & $\begin{array}{c}01 \\
(11.11) \\
\end{array}$ & $\begin{array}{c}05 \\
(55.56) \\
\end{array}$ & $\begin{array}{c}03 \\
(33.33) \\
\end{array}$ & $\begin{array}{c}05 \\
(55.56) \\
\end{array}$ & $\begin{array}{c}06 \\
(66.67) \\
\end{array}$ & \begin{tabular}{|c|}
03 \\
$(33.33)$ \\
\end{tabular} & $\begin{array}{c}04 \\
(44.44) \\
\end{array}$ & $\begin{array}{c}05 \\
(55.56) \\
\end{array}$ \\
\hline 6. & Citrobacte & $\begin{array}{c}06 \\
(100) \\
\end{array}$ & $\begin{array}{c}04 \\
(66.67) \\
\end{array}$ & $\begin{array}{c}03 \\
(50) \\
\end{array}$ & $\begin{array}{c}01 \\
(16.67) \\
\end{array}$ & $\begin{array}{c}01 \\
(16.67) \\
\end{array}$ & $\begin{array}{c}01 \\
(16.67) \\
\end{array}$ & $\begin{array}{c}00 \\
(00) \\
\end{array}$ & $\begin{array}{c}04 \\
(66.67) \\
\end{array}$ & $\begin{array}{c}01 \\
(16.67) \\
\end{array}$ & $\begin{array}{c}04 \\
(66.67) \\
\end{array}$ & $\begin{array}{c}01 \\
(16.67) \\
\end{array}$ & $\begin{array}{c}02 \\
(33.33) \\
\end{array}$ & $\begin{array}{c}04 \\
(66.67) \\
\end{array}$ & \begin{tabular}{|c|}
02 \\
$(33.33)$ \\
\end{tabular} & $\begin{array}{c}02 \\
(33.33) \\
\end{array}$ & $\begin{array}{c}04 \\
(66.67) \\
\end{array}$ \\
\hline 7. & Salmonella & $\begin{array}{c}04 \\
(80)\end{array}$ & $\begin{array}{c}02 \\
(40)\end{array}$ & $\begin{array}{c}02 \\
(40) \\
\end{array}$ & $\begin{array}{c}01 \\
(20)\end{array}$ & $\begin{array}{c}00 \\
(00) \\
\end{array}$ & $\begin{array}{c}00 \\
(00)\end{array}$ & $\begin{array}{c}00 \\
(00)\end{array}$ & $\begin{array}{c}01 \\
(20)\end{array}$ & $\begin{array}{c}01 \\
(20)\end{array}$ & $\begin{array}{c}03 \\
(60) \\
\end{array}$ & $\begin{array}{c}01 \\
(20)\end{array}$ & $\begin{array}{c}01 \\
(20)\end{array}$ & $\begin{array}{c}02 \\
(40)\end{array}$ & $\begin{array}{c}01 \\
(20)\end{array}$ & $\begin{array}{c}02 \\
(40) \\
\end{array}$ & $\begin{array}{c}02 \\
(40)\end{array}$ \\
\hline 8. & A. baumanni. (05) & $\begin{array}{c}04 \\
(80) \\
\end{array}$ & $\begin{array}{c}03 \\
(60) \\
\end{array}$ & $\begin{array}{c}02 \\
(40) \\
\end{array}$ & $\begin{array}{c}00 \\
(00) \\
\end{array}$ & $\begin{array}{c}01 \\
(20) \\
\end{array}$ & $\begin{array}{c}00 \\
(00) \\
\end{array}$ & $\begin{array}{c}00 \\
(00) \\
\end{array}$ & $\begin{array}{c}03 \\
(60) \\
\end{array}$ & $\begin{array}{c}00 \\
(00) \\
\end{array}$ & $\begin{array}{c}02 \\
(40) \\
\end{array}$ & $\begin{array}{c}02 \\
(40) \\
\end{array}$ & $\begin{array}{c}02 \\
(40) \\
\end{array}$ & $\begin{array}{c}03 \\
(60) \\
\end{array}$ & $\begin{array}{c}01 \\
(20) \\
\end{array}$ & $\begin{array}{c}02 \\
(40) \\
\end{array}$ & $\begin{array}{c}02 \\
(40) \\
\end{array}$ \\
\hline 9. & S. aureus. (24) & $\begin{array}{c}21 \\
(87.50) \\
\end{array}$ & $\begin{array}{c}20 \\
(83.33)\end{array}$ & $\begin{array}{c}12 \\
(50)\end{array}$ & $\begin{array}{c}05 \\
(20.83) \\
\end{array}$ & $\begin{array}{c}06 \\
(25)\end{array}$ & $\begin{array}{c}03 \\
(12.50)\end{array}$ & $\begin{array}{c}02 \\
(08.33) \\
\end{array}$ & $\begin{array}{c}22 \\
(91.67)\end{array}$ & $\begin{array}{c}09 \\
(37.50)\end{array}$ & $\begin{array}{c}18 \\
(75)\end{array}$ & $\begin{array}{c}12 \\
(50)\end{array}$ & $\begin{array}{c}16 \\
(66.67) \\
\end{array}$ & $\begin{array}{c}19 \\
(79.17)\end{array}$ & $\begin{array}{c}13 \\
(54.17)\end{array}$ & $\begin{array}{c}11 \\
(45.83)\end{array}$ & $\begin{array}{c}17 \\
(70.83) \\
\end{array}$ \\
\hline 10. & S. saprophyticus. (04) & $\begin{array}{c}03 \\
(75) \\
\end{array}$ & $\begin{array}{c}02 \\
(50) \\
\end{array}$ & $\begin{array}{c}01 \\
(25) \\
\end{array}$ & $\begin{array}{c}00 \\
(00) \\
\end{array}$ & $\begin{array}{c}00 \\
(00) \\
\end{array}$ & $\begin{array}{c}00 \\
(00) \\
\end{array}$ & $\begin{array}{c}00 \\
(00) \\
\end{array}$ & $\begin{array}{c}03 \\
(75) \\
\end{array}$ & $\begin{array}{c}01 \\
(25) \\
\end{array}$ & $\begin{array}{c}02 \\
(50) \\
\end{array}$ & $\begin{array}{c}01 \\
(25) \\
\end{array}$ & $\begin{array}{c}01 \\
(25) \\
\end{array}$ & $\begin{array}{c}02 \\
(50) \\
\end{array}$ & $\begin{array}{c}01 \\
(25) \\
\end{array}$ & $\begin{array}{c}02 \\
(50) \\
\end{array}$ & $\begin{array}{c}02 \\
(50) \\
\end{array}$ \\
\hline 11. & $\begin{array}{l}\text { E. faecalis. } \\
\text { (03) }\end{array}$ & $\begin{array}{c}03 \\
(100)\end{array}$ & $\begin{array}{c}03 \\
(100)\end{array}$ & $\begin{array}{c}01 \\
(33.33)\end{array}$ & $\begin{array}{c}01 \\
(33.33)\end{array}$ & $\begin{array}{c}01 \\
(33.33)\end{array}$ & $\begin{array}{c}01 \\
(33.33)\end{array}$ & $\begin{array}{c}00 \\
(00)\end{array}$ & $\begin{array}{c}03 \\
(100)\end{array}$ & $\begin{array}{c}01 \\
(33.33)\end{array}$ & $\begin{array}{c}02 \\
(66.67)\end{array}$ & $\begin{array}{c}01 \\
(33.33 \\
\end{array}$ & $\begin{array}{c}01 \\
(33.33)\end{array}$ & $\begin{array}{c}02 \\
(66.67)\end{array}$ & \begin{tabular}{|c|}
01 \\
$(33.33)$
\end{tabular} & $\begin{array}{c}02 \\
(66.67)\end{array}$ & $\begin{array}{c}02 \\
(66.67) \\
\end{array}$ \\
\hline & $\begin{array}{c}\text { Total }\left(n^{*}=152\right) \\
(\% \text { resistance })\end{array}$ & $\begin{array}{c}125 \\
(82.24)\end{array}$ & $\begin{array}{c}98 \\
(80.99) \\
\end{array}$ & $\begin{array}{c}49 \\
(40.50) \\
\end{array}$ & $\begin{array}{c}22 \\
(18.18)\end{array}$ & $\begin{array}{c}30 \\
(24.79) \\
\end{array}$ & $\begin{array}{c}24 \\
(19.83) \\
\end{array}$ & $\begin{array}{c}9 \\
(07.44)\end{array}$ & $\begin{array}{c}95 \\
(78.51) \\
\end{array}$ & $\begin{array}{c}39 \\
(32.23) \\
\end{array}$ & $\begin{array}{c}93 \\
(76.86) \\
\end{array}$ & $\begin{array}{c}76 \\
(62.81) \\
\end{array}$ & $\begin{array}{c}72 \\
(59.50)\end{array}$ & $\begin{array}{c}100 \\
(82.64)\end{array}$ & $\begin{array}{c}61 \\
(50.41) \\
\end{array}$ & $\begin{array}{c}57 \\
(47.11) \\
\end{array}$ & $\begin{array}{c}102 \\
(84.30) \\
\end{array}$ \\
\hline
\end{tabular}


Table.5 Percentage of ESBL producers

among Gram Negative Bacilli. (GNBs).

\begin{tabular}{|l|l|l|l|}
\hline S.No & Organisms & Non ESBL's (\%) & ESBL's (\%) \\
\hline 1. & E.coli $(49)$ & $35(28.93)$ & $14(11.57)$ \\
\hline 2. & Klebsiella sp. $(21)$ & $06(04.96)$ & $15(12.40)$ \\
\hline 3. & Proteus sp. $(16)$ & $10(08.26)$ & $06(04.96)$ \\
\hline 4. & Pseudomonas sp. $(10)$ & $07(05.79)$ & $03(02.48)$ \\
\hline 5. & Enterobacter sp. (09) & $06(04.96)$ & $03(02.48)$ \\
\hline 6. & Citrobacter sp. $(06)$ & $03(02.48)$ & $03(02.48)$ \\
\hline 7. & Salmonella sp. $(05)$ & $05(04.13)$ & $00(00)$ \\
\hline 8. & Acinetobacter sp. $(05)$ & $04(03.31)$ & $01(00.83)$ \\
\hline \multicolumn{2}{|l|}{ TOTAL $(\mathbf{n}=\mathbf{1 2 1})$} & $\mathbf{7 6}(\mathbf{6 2 . 8 0})$ & $\mathbf{4 5}(\mathbf{3 7 . 1 9})$ \\
\hline
\end{tabular}

Table.6 Percentage of carbapenemase producers among Gram Negative Bacilli. (GNBs)

\begin{tabular}{|l|l|l|l|}
\hline S.No & Organisms & Non Carbapenemase $\mathbf{( \% )}$ & Carbapenemase (\%) \\
\hline 1. & E.coli $(49)$ & $45(37.19)$ & $04(03.31)$ \\
\hline 2. & Klebsiella sp. $(21)$ & $13(10.74)$ & $08(06.61)$ \\
\hline 3. & Proteus sp. $(16)$ & $13(10.74)$ & $03(02.48)$ \\
\hline 4. & Pseudomonas sp. $(10)$ & $06(04.96)$ & $04(03.31)$ \\
\hline 5. & Enterobacter sp. $(09)$ & $07(05.79)$ & $02(01.65)$ \\
\hline 6. & Citrobacter sp. $(06)$ & $02(01.65)$ & $04(03.31)$ \\
\hline 7. & Salmonella sp. $(05)$ & $05(04.13)$ & $00(00)$ \\
\hline 8. & Acinetobacter sp. $(05)$ & $05(04.13)$ & $00(00)$ \\
\hline \multicolumn{2}{|l|}{ TOTAL $(\mathbf{n}=\mathbf{1 2 1})$} & $\mathbf{9 6}(\mathbf{7 9 . 3 4 )})$ & $\mathbf{2 5}(\mathbf{2 0 . 6 6 )}$ \\
\hline
\end{tabular}

\section{Carbapenemase}

Carbapenems belong to the $\beta$ - lactam group of antibacterial agents. The emergence and proliferation of bacteria resistant to this important group of dug are jeopardizing the use of carbapenems. The prevalence of carbapenemase production among Gram negative bacilli varies greatly from country to country and among the different regions within the country. Therapeutic options for infections caused by Gram negative bacteria expressing carbapenemases are limited. This emphasizes the need for detecting carbapenemases harboring isolates so as to avoid therapeutic failure and nosocomial outbreaks.
In the present study, $9.5 \%$ of Klebsiella spp. and $12.2 \%$ of E.coli isolates were found to be Meropenem (MRP) screen positive. Resistance to carbapenem was found to be more in Klebsiella spp. (6.6\%) than in E.coli (3.3\%). (Table.6). similarly, a high prevalence of resistance to carbapenems 31$51 \%$ in Klebsiella spp. and $2-13 \%$ in E.coli has been reported from other regions in India. (Wattal et al., 2010; Gupta et al., 2006 and Sathya et al., 2015).

In conclusion, the resistance profile of all the isolates I this study have shown that Imipenem, Meropenem, Chloramphenicol and Amikacin possess the high efficacy while Co-Trimaxazole, Norfloxacin, 
ceftriaxone and cefixime antibiotics shown the low efficacy against the pathogens causing Urinary Tract Infections (UTI's). Despite this efficacy, there was a general increase in this study compared with previous reports from this study area. Since majority of the clinics practice empiric therapy for UTI and the pathogens are demonstrating increasing antibiotic resistance, continuous updated data on antimicrobial patterns would be beneficial to those who practice empiric treatment. Controlling the emergence ad spread of ESBL organisms involves a combination of controlling antibiotic use ad strict adherence to hospital infection control measures. Restriction to one single class of antibiotics can lead to increase in resistance rates especially by ESBL production. Attempts have been made to decrease the prevalence of ESBL- producing organisms by substituting earlier cephalosporins or betalactamase inhibitor combinations. Klebsiella pneumoniae Carbapenemase (KPC) is becoming the primary type of carbapenemase responsible for CRE (Carbapemase Resistant Enterobacteriacae) in this study area (Mizoram). Residents of long-term care (chronic medical conditions) may be a major reservoir and source of KPCs. Hence, further studies are needed to determine risk factors for infection/colonization and to develop effective measures to prevent spreads in future.

It has been argued that there is a direct relation between the antibiotic used and the frequency and kind of antibiotic resistant strains in human beings. Misuse and selfmedication in our country is also a major problem as antibiotics could be purchased over the medicine counter or pharmacy shops without any prescription in India. This study highlights the needs for an antibiotic policy for its rationale use in our country. The policy should stress not only to prevent infections but also ensures the proper selection of antibiotics ad there should be minimum misuse of antibiotics. Clinicians must depend on more microbiological assays and reports for optimal UTI patient management.

\section{Acknowledgement}

The authors express gratitude to all the staff of the Department of nursing, Civil Hospital Aizawl who helped in collection of Data and samples from the bedside. No sources of funding were used to assist in the present study. We also wish to thank the staff of Microbiology section, Department of MLT, RIPANS for their constant support ad help in throughout this project work.

\section{References}

Babypadmini, S., B. Appalaraju. 2004. Extended spectrum $\beta$ - lactamase in urinary isolates of Escherichia coli and Klebsiella pneumonia prevalence ad susceptibility pattern in a tertiary care hospital. Indian J. Med. Microbiol.. 22(3): 172-174.

Bansal, M., Vyas, N., Sharma, B., et al. 2013. Differentiation of carbapenemase producing Enterobacteriaceae by triple disc test. Indian J. Basic Appl. Med. Res., 3: 314-320.

Bauer, A.W., Kirby, M.D.K., Sherries, J.C. and Truck, M. 1966. Antibiotic susceptibility testing by a standardized single disk method. American J. Clin. Pathol., 45: 493496.

Manikandan, C., Amsath, A. 2014. Antibiotic susceptibility patterns of Escherichia coli isolated from urine samples in Pattukottai, Tamilnadu. Int. J. Curr. Microbiol. App. Sci., 3(10): 449-457. 
Centers for Disease Control and Prevention; Guidance for control of infections with carbapenem-resistant or carbapenemase-producing enterobacteriacae in acute care facilities. MMWR 2009; 58: 256-259.

Cheesbrough, M. 2004. District Laboratory Practice in Tropical and Countries, Part-2. Cambridge University Press. United Kingdom.

Clinical Laboratory Standards Institute. M100-S22. 2012. Clinical and Laboratory Standards Institute: Performance Standards for Antimicrobial Susceptibility Testing. 22nd Informational Supplement. (M100- S22).Clinical and Laboratory Standards Institute. Vol. 31. No.1. January, 2012. Villanova. Pa. USA.

Clinical and Laboratory Standards Institute. 2011. Performance standards for antimicrobial susceptibility testing; 20th informational supplement. CLSI document M100-S21. CLSI, Wyne, PA.

Clinical Laboratory Standards Institute. M100-S22. 2012. Clinical and Laboratory Standards Institute: Performance Standards for Antimicrobial Susceptibility Testing. 22nd Informational Supplement. (M100- S22).Clinical and Laboratory Standards Institute. Vol. 31. No.1. January, 2012. Villanova. Pa. USA.

CLSI. 2010. Guidance for control of infections with carbapenem-resistant or carbapenemase producing Enterobacteriaceae in acute care facilities CLSI home. [Online] cited on March 30, 2010.

Daoud, Z.C., Moubareck, N., Hakime, Doucet, P. 2006. Extended spectrum $\beta$ - lactamase producing Enterobacteriaceae in Lebanese ICU patients: epidemiology and patterns of resistance. J. Gen. App. Microbiol., 52(3): 169-178.

Doumith, M., Ellington, M.J., Livermore, D.M. et al. 2009. Molecular mechanisms disrupting porin expression in ertapenem-resistant Klebsiella and Enterobacter spp. clinical isolates from the UK. $J$. Antimicrob. Chemother., 63: 659-67.

Faith, D.V., Thelma, E.T., Homer, G.A., Benilda, Q.B. and C. Cardano. 2003. Extended Spectrum $\beta$ - lactamase production among Escherichia coli and Klebsiella spp. at the Makati Medical Centre: Tentative Solutions. Phil. J. Microbiol. Infect. Dis., 32(3): 103-108.

Ferreira, C.m., Ferreira, W.A., Almeida, N.C., Naveca, F.G., Barbosa, Md. 2011. Extended Spectrum betalactamase producing bacteria isolated from haematologic patients in Manaus. State of Amazonas. Brazil. Brazilian J. Microbiol., 42: 10761084.

Gales, A.C., Jones, R.N., Gordon, K.A., Sader, H.S., Wilke, W.W., and Beach, M.L. 2000. Activity and spectrum of 22 antimicrobial agents tested against urinary tract infection pathogens in hospitalized patients in Latin America: report from the second year of the SENTRY Antimicrobial Surveillance Program 1998. J. Antimicrob. Chemother., 45: 156-163.

Gary, D.O., Margret, F.C. 2010. Carbapenemases: A brief review for pediatric infectious disease specialists. Pediatr. Infect. Dis. J., 29: 68-70.

Gupta, E., Mohanty, S., Sood, S., Dhawan, B., Das, B.K. ad Kapil, A. 2006. Emerging resistance to carbapenems in a tertiary care hospital in north 
India. Indian J. Med. Res., 124(1): 95-98.

Kariuki, S., Revathi, G., Corkill, J., Kiiru, J., Mwituria, J., Mirza, N. and Hart, C.A. 2007. Escherichia coli from commonly-acquired urinary tract infections resistant to flouroquinolones and extended spectrum beta-lactams. J. Infect. Developing. Count., 1: 257-262.

Karuppasamy, C., Lalsanglura ralte, Lydia Malsawmtluangi and Shelomith chawang. 2015. Prevalence of Extended Spectrum Beta Lactamases (ESBL) producing pathogens in raw milk samples collected from Aizawl Town, Mizoram. Indian J. Fund. \& Appl. Life Sci., Vol.5 (1). 332-340.

Karuppasamy, C., Lalsanglura Ralte. 2012. Resistance of the pathogens causing Urinary Tract Infections against antibiotics. Bioinfolet, 9(3): 348 354.

Knothe, H., Shah, P., Krčmery, V., Mitsuhashi, A.S. 1983. Transferable resistance to cefotaxime, cefoxitin, cefamandole and cefuroxime in clinical isolates of Klebsiella pneumoniae and Serratia marcescens. Infect., 11: 315-317.

Ko, K.S., Lee, M.Y., Song, J.H., Lee, H. Jug, S.J. ad Jung, S.I. 2008. Prevalence and Characterization of extended - spectrum $\beta$ - lactamase producing Enterobacteriacae isolated in Korean hospitals. Diag. Microbiol. Infect. Dis., 61: 453-459.

Livermore, D.M. 1995. $\beta$-Lactamases in laboratory and clinical resistance. Clin.Microbiol. Rev., 8: 557-584.

Lautenbach, E., Patel, J.B., Bilker, W.B., Edelstein, P.H., Fishman, N.O. 2001. Extended-spectrum B-lactamasesproducing Escherichia coli and Klebsiella pneumoniae: risk factors for infection and impact on resistance of outcomes. Clin. Infect. Dis., 32: 1162-1171.

Mahon, C.R., Lehman, D.C. and Manuselis, G. 2007. Textbook of Diagnostic Microbiology, 3rd edition, Saunders, Missouri.

Maikandan, S., S. Ganesapandian, Maoj Sigh and A.K. Kumaraguru. 2011. Antimicrobial Susceptibility pattern of Urinary Tract Infection causing Human pathogenic bacteria. Asian J. Med. Sci., 3(2): 56-60.

Martinez-Martinez, L., Pascual, A., Hernandez-Alles, S. et al. 1999. Roles of b-lactamases and porins in activities of carbapenems and cephalosporins against Klebsiella pneumoniae. Antimicrobial Agents Chemother., 43: 1669-73.

Mehrgan, H., Rahbar, M. 2008. Prevalence of extended spectrum $\beta$ - lactamase producing in a tertiary care hospital in Tehran, Iran. It. J. Antimicrob. Agents, 31: 147-151.

Mustafa, O.A., Yusuf, D. and Ahmet, U. 2009. Investigation of Imipenem and Meropenem Susceptibilities, Plasmid Profiles ad EBSL Charecteristic of Klebsiella pneumoniae Isolated from Urinary Tract Infections. World Appl. Sci. J., 7(3): 378-381.

National Committee for Clinical Laboratory Standards. Methods for Disc Susceptibility Test for Bacteria that Grows Aerobically. NCCLS. Document. M2.A7. Wayne, National Committee fro Clinical Laboratory Standards. $7^{\text {th }}$ edition. 2000

Oreste, A.M. 2003. Bacteria versus Antibacterial agents, an integrated approach. American Soc. Microbiol., (ASM Press) 172-182.

Prakash, B., Perumal, P., Jagdeesh Kumar, D. and Tamilini, P. 2012. Molecular Characterization of Plasmid Mediated ESBL Resistant Salmonella isolated 
from Poultry Environment in Namakkal District (India). Adv. Biotech., Vol.12 (2): 18-21.

Rastogi, V., Nirwan, P.S., Jain, S., Kapil, A. 2010. Nosocomial outbreak of Septicemia neonatal intensive care unit due to extended spectrum $\beta-$ lactamase producing Klebsiella pneumonia showing multiple mechanisms of drug resistance. Ind. $J$ Med. Micobiol., 28: 380-4.

Sathya, P., Shamsadh, B., Anbumani, N. 2015. Phenotypic Detection Methods of Carbapenemase Production in Enterobacteriaceae. Int. J Cur. Micro. \& App. Sci., Vol.4. (6). 547-552.

Schwaber, M., Carmeli, Y. 2006. Antimicrobial resistance and patient outcomes: The hazards of adjustment. Crit care, 10: 164.

Swenson, M.J., Hindler, J.F., Jorgensen, H.J. 2007. Special Phenotypic Methods for Detecting Antibacterial Resistance In: Baron E J, Jorgensen J H, Landry M L, Pfaller M A, eds,
Manual of Clinical Microbiology, $9^{\text {th }}$ ed; vol.1 Washington DC: ASM Press, pp.1180-1182.

Tenover, C.F. 2006. Mechanisms of Antimicrobial Resistance in Bacteria. AM. J. Med., 119 (6A).

Wada, K., Kariyama, R., Mitsuhata, R., Uehara, S., Wataabe, T., Monden, K. and Kumon, H. 2009. Experimental and clinical studies $\mathrm{O}$ fluoroquinolones- insusceptible Escherichia coli isolated from patients with urinary tract infections from 1994 to 2007. Acta. Med. Okayama, 63: 263-272.

Wattal Wattal, C., Joshi, S., Sharma, A., Oberoi, J.K., Prasad, K.J. 2005. Prescription auditing and antimicrobial resistance at a tertiary care hospital at New Delhi, India. $J$. Hosp. Infect., 59: 156-8.

\section{How to cite this article:}

Karuppasamy Chellapandi, Lalsanglura Ralte, Manika Basumatari, K. Amitra and Rickybirth M. Sangma. 2016. Occurrence of Multi Drug Resistant, ESBL and Carbapenemase Enzymes Producing Gram Negative Urinary Pathogens in Aizawl, Mizoram, India. Int.J.Curr.Microbiol.App.Sci. 5(8): 233-247. doi: http://dx.doi.org/10.20546/ijcmas.2016.508.024 